\title{
Cohen syndrome diagnosis using whole genome arrays
}

\author{
Nuria Rivera-Brugués, ${ }^{1}$ Beate Albrecht, ${ }^{2}$ Dagmar Wieczorek, ${ }^{2}$ Heinrich Schmidt, ${ }^{3}$ \\ Thomas Keller, ${ }^{4}$ Ina Göhring, ${ }^{5}$ Arif B Ekici, ${ }^{5}$ Andreas Tzschach, ${ }^{6}$ Masoud Garshasbi, ${ }^{6}$ \\ Kathlen Franke, ${ }_{1}^{7}$ Norman Klopp ${ }^{8}$ H-Erich Wichmann, ${ }^{8}$ Thomas Meitinger, ${ }^{1,9}$ \\ Tim M Strom, ${ }^{1,9}$ Maja Hempel ${ }^{1,9}$
}

'Institute of Human Genetics, Helmholtz Zentrum München, Neuherberg, Germany

${ }^{2}$ Institut für Humangenetik, Universitätsklinikum Essen, Essen, Germany

${ }^{3}$ Department of Pediatrics, Ludwig-Maximilians-Universität, Munich, Germany

${ }^{4}$ Department of Pediatrics, Josefinum Augsburg, Augsburg, Germany

${ }^{5}$ Institute of Human Genetics, Friedrich-Alexander-University Erlangen-Nuremberg, Erlangen, Germany

${ }^{6}$ Max Planck Institute for Molecular Genetics, Department Human Molecular Genetics,

Berlin, Germany

${ }^{7}$ Private Clinic B.Prager \& A.

Junge, Dresden, Germany

${ }^{8}$ Institute of Epidemiology, Helmholtz Zentrum München, Neuherberg, Germany ${ }^{9}$ Institute of Human Genetics, Technische Universität München, Munich, Germany

\section{Correspondence to}

Dr Maja Hempel, Institute of Human Genetics, Technische Universität München,

Trogerstraße 32, D-81675

Munich, Germany;

hempel@humangenetik.med. tu-muenchen.de

Received 21 June 2010 Revised 12 August 2010 Accepted 17 August 2010 Published Online First 4 October 2010

\begin{abstract}
Background Cohen syndrome is a rare autosomal recessive disorder with a complex phenotype including psychomotor retardation, microcephaly, obesity with slender extremities, joint laxity, progressive chorioretinal dystrophy/myopia, intermittent isolated neutropenia, a cheerful disposition, and characteristic facial features. The $\mathrm{COH} 1$ gene, which contains 62 exons, is so far the only gene known to be associated with Cohen syndrome. Point mutations, deletions and duplications have been described in this gene. Oligonucleotide arrays have reached a resolution which allows the detection of intragenic deletions and duplications, especially in large genes such as $\mathrm{COH1}$.
\end{abstract}

Method and results High density oligonucleotide array data from patients with unexplained mental retardation $(n=1523)$ and normal controls $(n=1612)$ were analysed for copy number variation (CNV) changes. Intragenic heterozygous deletions in the $\mathrm{COH} 1$ gene were detected in three patients but no such changes were detected in the controls. Subsequent sequencing of the $\mathrm{COH} 1$ gene revealed point mutations in the second allele in all three patients analysed.

Conclusion Genome-wide CNV screening with high density arrays provides a tool to detect intragenic deletions in the $\mathrm{COH} 1$ gene. This report presents an example of how microarrays can be used to identify autosomal recessive syndromes and to extend the phenotypic and mutational spectrum of recessive disorders.

\section{INTRODUCTION}

The phenotype of Cohen syndrome (MIM 216550), a rare autosomal recessive disorder, has been described to be fairly homogeneous in Finnish patients where the founder mutation c.3348_3349delCT is detected in about $75 \%$ of mutant alleles. ${ }^{1}$ But in non-Finnish and especially in young Cohen patients, a high genotypic and phenotypic variability occurs. Several clinical diagnostic criteria for Cohen syndrome have been introduced. $^{2-5}$ Chandler et al proposed that, next to significant learning disabilities, two of the following criteria should be present for Cohen syndrome diagnosis: facial gestalt, pigmentary retinopathy, and neutropenia. ${ }^{3}$ Kohlemainen et al suggested Cohen syndrome in patients fulfilling at least six of the following criteria: developmental delay, microcephaly, typical facial gestalt, truncal obesity with slender extremities, overly sociable behaviour, joint hypermobility, high myopia and/or retinal dystrophy, and neutropenia. ${ }^{5}$ El Chehadeh et al concluded that mutation analysis is not indicated in the absence of chorioretinal dystrophy or neutropenia. ${ }^{6}$

The COH1 gene (VPS13B, MIM 607817), so far the only gene known to be associated with Cohen syndrome, is one of the largest known genes in the human genome and comprises 62 exons distributed along $864315 \mathrm{bp}$ of chromosome 8. More than 96 different mutations in $\mathrm{COH} 1$ gene have been detected in association with Cohen syndrome. The majority of them are terminating mutations predicted to result in a functional null allele. ${ }^{5}$ 7-9 Recently large intragenic deletions and duplications in the $\mathrm{COH} 1$ gene have been identified as a cause of Cohen syndrome. ${ }^{10} 11$ Molecular diagnosis of syndromes has been improved by the introduction of oligonucleotide arrays which have reached a resolution facilitating the detection of intragenic copy number variations (CNVs).

\section{ARRAY DATASETS AND METHODS Array datasets}

Recruitment of patients ( $n=1523$ ) had been part of the German Mental Retardation Network (MRNET) study (http://www.german-mrnet.de/). In the present study we focus on three patients, in which $\mathrm{CNV}$ s in the $\mathrm{COH} 1$ gene were detected. As a control set, CNV data $(n=1612)$ had been generated from the population based KORA study (Cooperative Health Research in the Augsburg Region).

\section{CNV analysis}

Genome-wide screening for CNVs was performed using the Infinium Human550 Genotyping BeadChip (Illumina, SanDiego, California, USA) in patients 1 and 2 and the Genome-Wide Human SNP Array 6.0 (Affymetrix, Santa Clara, California, USA) in patient 3 . The controls have been investigated with Illumina Infinium Human550-Quad or Human610-Quad arrays.

The genomic DNA of the patients and controls was isolated from peripheral blood lymphocytes according to standard procedures and processed following the manufacturer's instructions. Arrays were scanned with the Illumina BeadArray Reader and with the Affymetrix Scanner 3000 7G. Genotypes were called with the Illumina GenomeStudio Software or using the Affymetrix Genotyping Console Software (version 3.0.2), respectively. 
Data analysis of the Illumina arrays was performed according to Wagenstaller et al. ${ }^{12} \mathrm{CNV}$ profiling of the Affymetrix array data was accomplished by using the Segment reporting Tools of the Genotyping Console Software. To determine a deletion we used as a cut-off the smoothing median of five or more adjacent single nucleotide polymorphisms (SNPs) with copy number values $\leq 1.5$ or with log2 intensity ratios $\leq-1$ for Illumina and Affymetrix arrays, respectively. CNVs with copy number values $\geq 2.5$ or with $\log 2$ intensity ratios $\geq 1$ were suspicious for duplication. All CNVs were checked for gene content and overlap with known genetic variants as provided by the genome browser of the University of California Santa Cruz (UCSC) (http://genome.ucsc.edu, hg 18) and the Database of Genomic Variants (DGV, http://projects.tcag.ca/variation). CNVs not annotated as structural polymorphisms and containing RefSeq genes were genotyped by quantitative PCR (qPCR). Monitoring of the PCR reaction and setting of baseline and threshold cycle values were accomplished automatically with the Sequence Detection System Version 2.3 Software (SDS 2.3, Applied Biosystems, Darmstadt, Germany). The relative quantification analysis based on the comparative $C_{t}$ method was performed using an in-house developed Perl script.

\section{Sequencing}

In the patients with a partial heterozygous deletion of the $\mathrm{COH} 1$ gene, direct sequencing of the entire coding region and the exon/intron boundaries of $\mathrm{COH} 1$ was carried out using BigDye Ready Terminator Sequencing Kit and an 48 capillary Abi 3730 Genetic Analyzer (Applied Biosystems) in accordance with standard procedures. All identified variants were genotyped in 676 individuals of a population based cohort (KORA-cohort) via the MassARRAY system (Sequenom genotyping platform) and the iPLEX Gold chemistry. The assay design used the AssayDesign 3.1.2.2 software with default parameters. Genotype calling was performed by the SpectroTYPER 3.4 software.

\section{Nomenclature}

Gene model NM_17890.3/NP_060360 based on UCSC browser was used to describe the detected COH1 gene variants (http:// genome.ucsc.edu hg18).
Patient 1

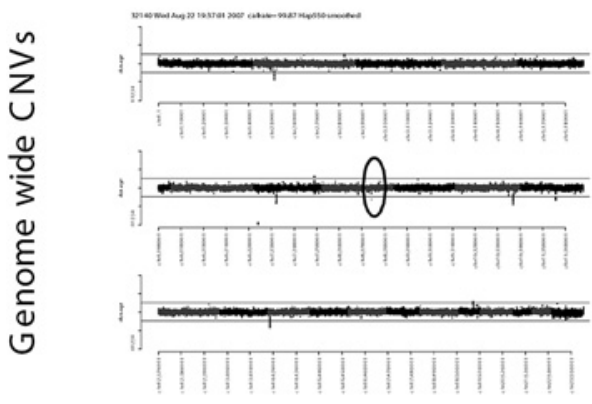

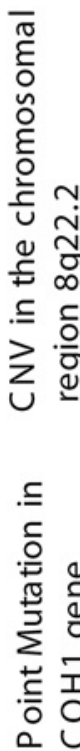

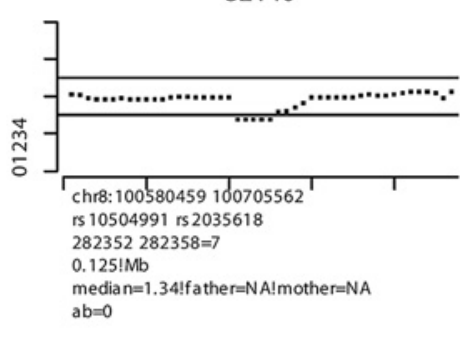

c.5197C >T
Patient 2

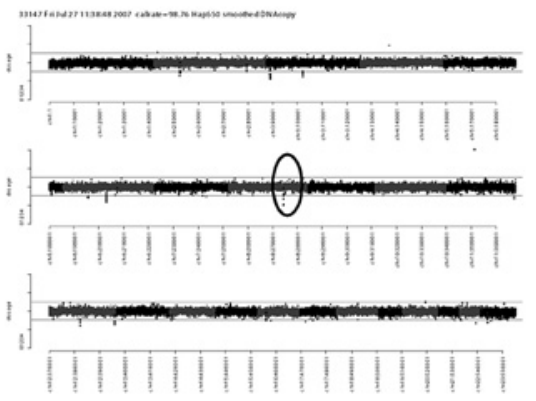

33147

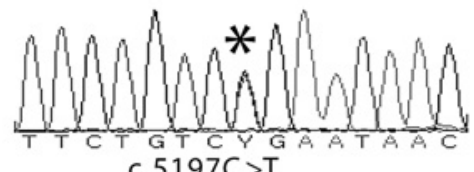

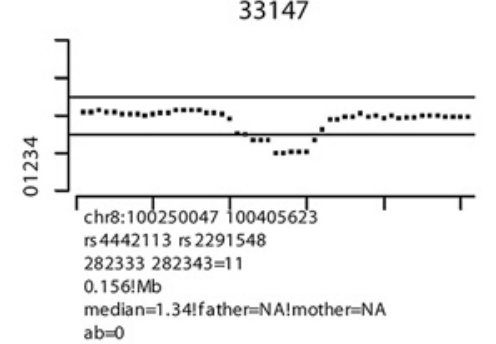

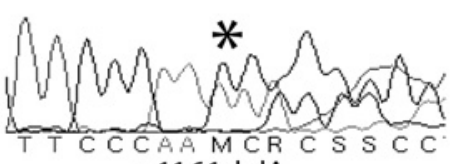

c. 1161 delA
Patient 3
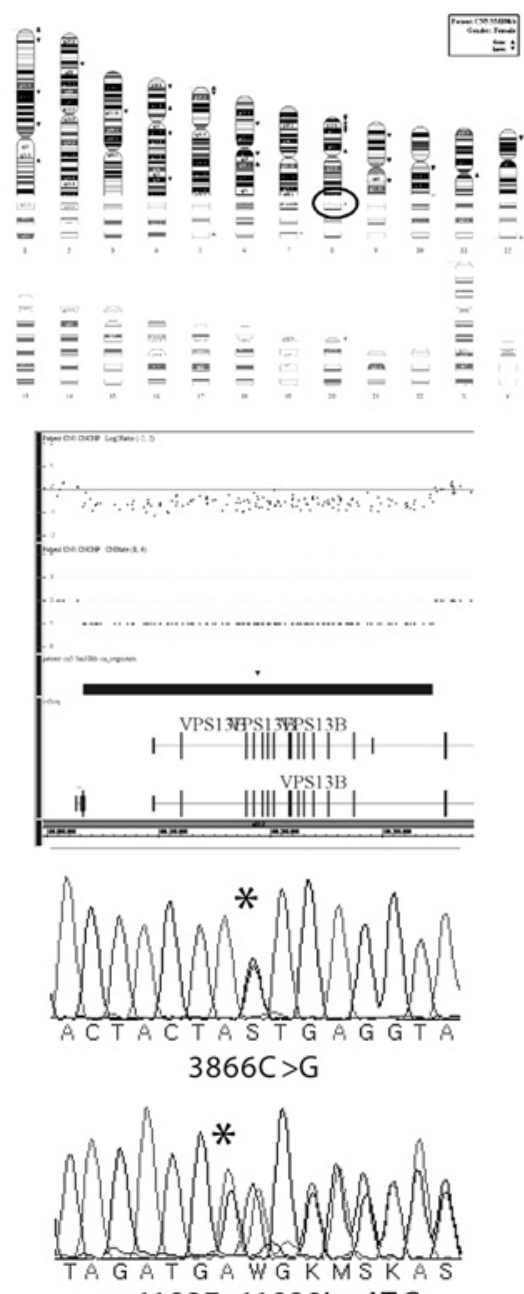

c.11827_11828ins ATG

Figure 1 Array results and electropherograms of the $\mathrm{COH} 1$ mutations in patients 1 to 3 . Patient 1 is affected by a $125 \mathrm{~kb}$ deletion encompassing exons 26 to 31 of the $\mathrm{COH} 1$ gene (chr.8: $100563167 \ldots 100642020$ ) and a missense mutation c.5197C $\rightarrow$ T of the second allele. In Patient 2 a $156 \mathrm{~kb}$ deletion encompassing exons 16 to 19 of the $\mathrm{COH} 1$ gene (chr.8:100 $250047 \ldots 100405623$ ) and a one base pair deletion c.1161delA in the second allele was detected. In Patient 3 a $315 \mathrm{~kb}$ deletion encompassing exons 1 to 17 of the COH1 gene (chr8:100 015029...100347 846) and missense mutation 3866C $\rightarrow \mathrm{G}$ and three base pair insertion c.11827_11828insATG in the second allele were found. CNV, copy number variation. 
Figure 2 Craniofacial phenotype of patients 1 to 3 . Patient 1 at the age of 3 years with horizontal eyebrows, a broad and down turned nasal tip, a broad columella, a short philtrum, a small upper lip and everted lower lip. Patient 2 at the age of 18 months with horizontal eyebrows, almond shaped and downslanting palpebral fissures, a broad nasal root, a round nasal tip, thick columella, a short philtrum, and open appearance of mouth with prominent upper gingiva. Patient 3 at the age of $2^{8} / 12$ years with round and flat face, bushy eyebrows with lateral flaring, broad nasal bridge, short philtrum and microtia with overfolded helices.
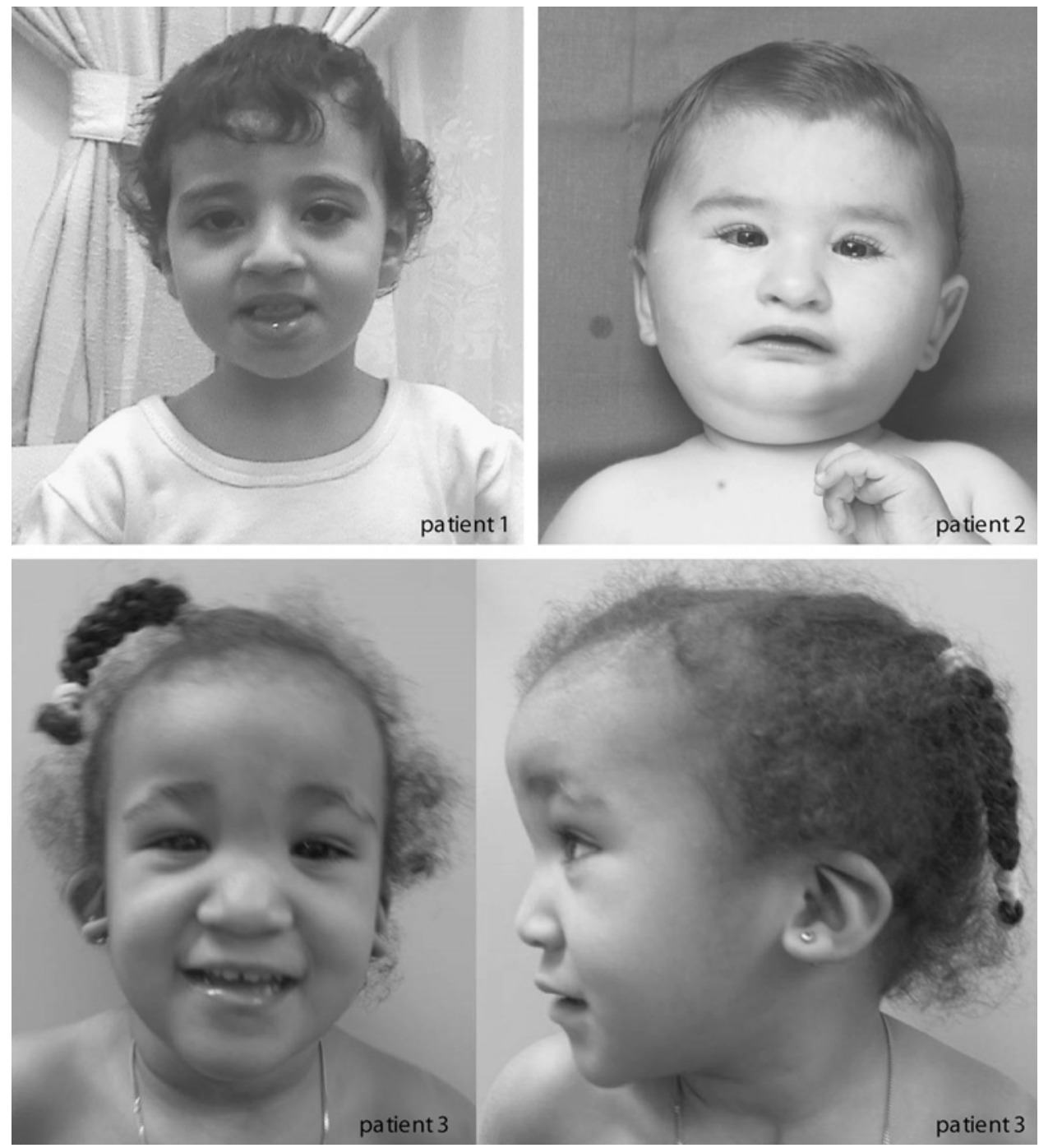

\section{RESULTS}

\section{Molecular findings}

Analysis of SNP oligonucleotide array and subsequent qPCR discovered CNVs in the COH1 gene in three patients: a maternal $67 \mathrm{~kb}$ deletion encompassing exons 26 to 31 of the $\mathrm{COH} 1$ gene (chr8: 100573 090...100 639 924; c.3871-5024del/p.G1291fsX42) in patient 1 , a paternal $193 \mathrm{~kb}$ deletion encompassing exons 9 to 19 of the COH1 gene (chr8: $100216034 \ldots 100409167$; c.1207$2824 \mathrm{del} / \mathrm{p}$.L403fsX11) in patient 2 , and a maternal $315 \mathrm{~kb}$ deletion encompassing exon 4 of the OSR 2 gene and exons 1 to 17 of the COH1 gene (chr8:100 015029...100347846; c.1-2515del) in patient 3 (figure 1). There were no such changes in the 1612 controls.

Sequencing of the $\mathrm{COH} 1$ gene identified in patient 1 a paternal missense mutation in exon 32 leading to a stop codon (c.5086C $\rightarrow \mathrm{T} / \mathrm{p} . \mathrm{R} 1696 \mathrm{X}$ ), in patient 2 a maternal $1 \mathrm{bp}$ deletion in exon 60 leading to a stop codon (c.11505delA/p.K3835fsX43), and in patient 3 a heterozygous missense mutation in exon 25 (c.3866C $\rightarrow \mathrm{G} / \mathrm{p} . \mathrm{T} 1289 \mathrm{~S}$ ) and a heterozygous three base pairs insertion in exon 62 (c.11827_11828insATG/p.D3942 G3943insD), both inherited from the father (figure 1). These mutations were not present in 676 samples from a general population cohort (KORA) and not annotated as polymorphisms in dbSNP (NCBI, http://www.ncbi.nlm.nih. gov/SNP).

\section{Clinical data}

\section{Patient 1}

The boy was born after an uneventful pregnancy at term as the first child of unrelated and healthy Arabian parents. Birth weight, length and head circumference were not recorded. A delay in motor development became evident within his first year of life. Sitting started at the age of 18 months, walking at 24 months. A detailed examination at the age of 3 years showed a hypotonic boy with a height of $79 \mathrm{~cm}(-4.8 \mathrm{SD})$, a weight of $9300 \mathrm{~g}(-5.2 \mathrm{SD})$, and a head circumference of $44 \mathrm{~cm}$ ( $-4.9 \mathrm{SD})$. A delay in speech development as well as in comprehension was obvious. There was mild craniofacial dysmorphism including horizontal eyebrows, a broad and downturned nasal tip, a broad columella, a short philtrum, a thin upper lip, and an everted lower lip (figure 2). The ophthalmologic examination revealed bilateral myopia, astigmatism and a slightly increased pigmentation of the retina. There was no neutropenia.

\section{Patient 2}

This boy was born at term after an uneventful pregnancy as the second child of healthy unrelated German parents, with a birth weight of $2460 \mathrm{~g}(-2.4 \mathrm{SD})$, a birth length of $46.5 \mathrm{~cm}(-2.3 \mathrm{SD})$, and a head circumference of $31.5 \mathrm{~cm}(-2.9 \mathrm{SD})$. Developmental milestones were delayed with a sitting age of 12 months and a crawling age of 17 months. Examination at the age of 
18 months showed a hypotonic toddler with a weight of $10.1 \mathrm{~kg}$ $(-1.5 \mathrm{SD})$, a height of $80 \mathrm{~cm}(-1 \mathrm{SD})$, and a severe microcephaly with an occipitofrontal circumference (OFC) of $42.5 \mathrm{~cm}(-4.8$ $\mathrm{SD})$. Speech development had not occurred but comprehension was nearly normal. Facial dysmorphism consisted of mild occipital flattening, horizontal eyebrows, almond shaped palpebral fissures, a broad nasal root, a round nasal tip, a thick columella, a short philtrum, an open appearance of the mouth with a prominent upper gingiva, and a large gap between the incisors (figure 2). Funduscopy and complete blood count revealed no abnormalities.

\section{Patient 3}

The patient is the second child of a healthy non-consanguineous German/African couple. The premature birth occurred at 35 weeks of gestation with a birth weight of $2450 \mathrm{~g}(-0.1 \mathrm{SD})$, a birth length of $46 \mathrm{~cm}(-0.4 \mathrm{SD})$, and an $\mathrm{OFC}$ of $33.5 \mathrm{~cm}(0.6$ $\mathrm{SD})$. A heart defect (atrioseptal defect (ASD) II and pulmonary stenosis) and arrhythmia were diagnosed after birth. Developmental delay persisted until 2 years of age and improved after surgical correction of the heart defect. The patient started to walk at the age of 24 months and at the age of $2^{3} / 4$ years she showed normal body measurement with a height of $95 \mathrm{~cm}(0.4$ $\mathrm{SD})$, a weight of $11.5 \mathrm{~kg}(-1.4 \mathrm{SD})$, and an OFC $50 \mathrm{~cm}(0.6 \mathrm{SD})$. She had a flat face with broad and flat nasal bridge and almond shaped eyes, a short philtrum with thin vermillion border, and deep set ears with overfolded helices (figure 2). Funduscopy and complete blood count revealed normal results.

\section{DISCUSSION}

Our report demonstrates that the diagnosis of Cohen syndrome can be reached in patients with unexplained mental retardation by applying high resolution oligonucleotide arrays. Although multiple exon deletions in the $\mathrm{COH} 1$ gene have been reported in single patients, 57813 the distribution of deletions and duplications has only been recognised recently. ${ }^{10}{ }^{11}$ The frequency of copy number alterations in the $\mathrm{COH} 1$ gene is unknown. Parri et al disclosed that $\mathrm{COH} 1 \mathrm{CNVs}$ account for $42 \%$ of $\mathrm{COH} 1$ mutations. ${ }^{11}$ Balikova et al reported an increase in the detection rate of $18 \%(88 \%$ instead of $70 \%)$ in typical Cohen patients. ${ }^{10}$ Arrays targeted at individual exons will further increase the detection rate. We have recently identified-by molecular analysis-a homozygous $66 \mathrm{~kb}$ deletion comprising exons 32 and 33 of $\mathrm{COH} 1$ which had escaped detection by current array comparative genomic hybridisation $(\mathrm{CGH})$ analysis. The fact that we failed to detect CNVs in the COH1 gene in 1612 controls from a general German population cohort indicates that CNVs in the COH1 gene are rare. This is in contrast to the annotation of the COH1 gene CNVs as benign polymorphisms in the UCSC genome browser and the DGV.

To our knowledge this is the first report on patients with Cohen syndrome diagnosed by molecular whole genome analyses but not by clinical examination. Cohen syndrome was not suspected at first instance in the patients, although all of them were examined by experienced paediatricians or clinical geneticists. This can be explained by the young age of patients (16 months, 18 months, $2 \frac{3}{4}$ years). The facial appearance of the infant and young children with Cohen syndrome differs from adult patients and myopia/retinal pigmentary changes usually develop in the pre-school age. ${ }^{3}$ The common facial characteristics in our small series of young patients with Cohen syndrome were a hypotonic facial expression, almond shaped palpebral fissures, a prominent nose, and a short philtrum. All patients were affected by mental retardation and delay in motor and speech development. Pigmentary retinopathy and neutropenia were absent in all patients. The unusual phenotype in patient 3 may due to the fact that in addition to exons 1 to 17 of the $\mathrm{COH} 1$ gene, the deletion affected the neighbouring exon 4 of the ORS2 gene. Although the gene function of ORS2 in humans is unknown, an influence of the phenotype cannot be ruled out.

In conclusion, the phenotype of Cohen syndrome defined by $\mathrm{COH} 1$ mutations is fairly unspecific, particularly in very young patients but in older children too. In addition, deletions in neighbouring genes may affect the phenotype of Cohen syndrome in the context of a contiguous gene syndrome. Nevertheless, young patients with a hypotonic facial expression, almond shaped eyes, short philtrum, mental retardation, and motor and speech delay are suspicious for Cohen syndrome. Microarrays have the potential to diagnose Cohen syndrome in very young patients and in patients with an atypical phenotype.

\begin{abstract}
Acknowledgements We thank all patients and their families for participating in this study. We thank Peter Lichtner, Institute of Human Genetics, Helmholtz Zentrum München for genotyping the $\mathrm{COH}$ variants in controls and Jürgen Kohlhase, Center for Human Genetics, Freiburg for CHD7 mutation analysis in patient 3. We also thank Monika Hartig, llona Dugdale and Lawrence Haw for critical revision of the manuscript and editorial assistance. This work was supported by a grant from the German Ministry for Education and Research (NGFNplus/http://www.ngfn.de/ englisch/15.htm, project reference numbers 01GS08160, 01GS08161, $01 \mathrm{GS} 08163$ and 01GS08167). The research was conducted within the MRNET consortium (http://www.german-mrnet.de/).
\end{abstract}

Funding NGFN Geschäftsstelle; c/o Deutsches Krebsforschungszentrum - DKFZIm Neuenheimer Feld 580, V025; 69120 Heidelberg. Other funders: BMBF, Germany.

Competing interests None.

Patient consent Obtained.

Ethics approval Approval for the study had been obtained by the ethical review boards of the participating institutions.

Provenance and peer review Not commissioned; externally peer reviewed.

\section{REFERENCES}

1. Kolehmainen J, Black GC, Saarinen A, Chandler K, Clayton-Smith J, Träskelin AL, Perveen R, Kivitie-Kallio S, Norio R, Warburg M, Fryns JP, de la Chapelle A, Lehesjok $\mathrm{AE}$. Cohen syndrome is caused by mutations in a novel gene, $\mathrm{COH} 1$, encoding a transmembrane protein with a presumed role in vesicle-mediated sorting and intracellular protein transport. Am J Hum Genet 2003;72:1359-69.

2. Horn D, Krebsova A, Kunze J, Reis A. Homozygosity mapping in a family with microcephaly, mental retardation, and short stature to a Cohen syndrome region on 8q21.3-8q22.1: redefining a clinical entity. Am J Med Genet 2000;92:285-92.

3. Chandler KE, Kidd A, Al-Gazali L, Kolehmainen J, Lehesjoki AE, Black GC, ClaytonSmith J. Diagnostic criteria, clinical characteristics, and natural history of Cohen syndrome. J Med Genet 2003;40:233-41.

4. Mochida GH, Rajab A, Eyaid W, Lu A, Al-Nouri D, Kosaki K, Noruzinia M, Sarda P, Ishihara J, Bodell A, Apse K, Walsh CA. Broader geographical spectrum of Cohen syndrome due to $\mathrm{COH} 1$ mutations. J Med Genet 2004:41:e87.

5. Kolehmainen J, Wilkinson R, Lehesjoki AE, Chandler K, Kivitie-Kallio S, ClaytonSmith J, Träskelin AL, Waris L, Saarinen A, Khan J, Gross-Tsur V, Traboulsi El, Warburg M, Fryns JP, Norio R, Black GC, Manson FD. Delineation of Cohen syndrome following a large-scale genotype-phenotype screen. Am J Hum Genet 2004; 75:122-7.

6. El Chehadeh S, Aral B, Gigot N, Thauvin-Robinet C, Donzel A, Delrue MA, Lacombe D, David A, Burglen L, Philip N, Moncla A, Cormier-Daire V, Rio M, Edery P, Verloes A, Bonneau D, Afenjar A, Jacquette A, Heron D, Sarda P, Pinson L, Doray B, Vigneron J, Leheup B, Frances-Guidet AM, Dienne G, Holder M, Masurel-Paulet A, Huet F, Teyssier JR, Faivre L. Search for the best indicators for the presence of a VPS13B gene mutation and confirmation of diagnostic criteria in a series of 34 patients genotyped for suspected Cohen syndrome. J Med Genet 2010;47:549-53.

7. Seifert W, Holder-Espinasse M, Spranger S, Hoeltzenbein M, Rossier E, Dollfus $H$, Lacombe D, Verloes A, Chrzanowska KH, Maegawa GH, Chitayat D, Kotzot D, Huhle D, Meinecke P, Albrecht B, Mathijssen I, Leheup B, Raile K, Hennies HC, Horn D. Mutational spectrum of $\mathrm{COH} 1$ and clinical heterogeneity in Cohen syndrome. J Med Genet 2006;43:e22. 
8. Seifert W, Holder-Espinasse M, Kuhnisch J, Kahrizi K, Tzschach A, Garshasbi M, Najmabadi H, Walter Kuss A, Kress W, Laureys G, Loeys B, Brilstra E, Mancini GM, Dollfus H, Dahan K, Apse K, Hennies HC, Horn D. Expanded mutational spectrum in Cohen syndrome, tissue expression, and transcript variants of $\mathrm{COH} 1$. Hum Mutat 2009;30:E404-20.

9. Hennies HC, Rauch A, Seifert W, Schumi C, Moser E, Al-Taji E, Tariverdian G, Chrzanowska KH, Krajewska-Walasek M, Rajab A, Giugliani R, Neumann TE, Eckl KM, Karbasiyan M, Reis A, Horn D. Allelic heterogeneity in the $\mathrm{COH} 1$ gene explains clinical variability in Cohen syndrome. Am J Hum Genet 2004;75:138-45.

10. Balikova I, Lehesjoki AE, de Ravel TJ, Thienpont B, Chandler KE, Clayton-Smith J, Träskelin AL, Fryns JP, Vermeesch JR. Deletions in the VPS13B (COH1) gene as a cause of Cohen syndrome. Hum Mutat 2009;30:E845-54.
11. Parri V, Katzaki E, Uliana V, Scionti F, Tita R, Artuso R, Longo I, Boschloo R, Vijzelaar R, Selicorni A, Brancati F, Dallapiccola B, Zelante L, Hamel CP, Sarda P, Lalani SR, Grasso R, Buoni S, Hayek J, Servais L, de Vries BB, Georgoudi N, Nakou S, Petersen $\mathrm{MB}$, Mari F, Renieri A, Ariani F. High frequency of $\mathrm{COH} 1$ intragenic deletions and duplications detected by MLPA in patients with Cohen syndrome. Eur J Hum Genet 2010;10:1133-40.

12. Wagenstaller J, Spranger S, Lorenz-Depiereux B, Kazmierczak B, Nathrath M, Wahl $D$, Heye B, Glaser D, Liebscher V, Meitinger T, Strom TM. Copy-number variations measured by single-nucleotide-polymorphism oligonucleotide arrays in patients with mental retardation. Am J Hum Genet 2007;81:768-79.

13. Taban M, Memoracion-Peralta DS, Wang H, Al-Gazali LI, Traboulsi El. Cohen syndrome: report of nine cases and review of the literature, with emphasis on ophthalmic features. J AAPOS 2007;11:431-7.

\section{Poetry}

\section{The battle of replication fork}

Small soldiers march swiftly, the battle draws near Helicase from the cannons split legions, no fear Commanders ride forth with bellowing calls Sending signals to primers, engage, pair them all! Deoxy stands back, a path must be made Those RNA boys bear the brunt of the trade At last help's arrived; they've come through the trees 3-primed and ready, polymerase threes RNA clears the field, a job nicely done Their stations soon filled by polymerase one "Who leads?" cries the general, he asks for a name It's 3-prime not 5 , the phosphates to blame Fragmented and lagging are the men from Japan Send ligase post haste, it's part of the plan The fighting drones on, with no end in sight
Gyrase eases tensions, gets men through the night At last the sun rises, dust settles, all clear Polymerase checks that the win is sincere Not a moment for rest, they're worked to the ground For over those hills, more ori abound

\section{Victor Laurion}

Correspondence to Victor Laurion, Bryn Mawr College, 900 Montgomery Avenue, Bryn Mawr, PA 19010, USA; victor.laurion@gmail.com

Competing interests None declared.

Provenance and peer review Not commissioned; not externally peer reviewed.

Received 20 October 2010

Accepted 16 November 2010

Published Online First 22 December 2010

J Med Genet 2011;48:140. doi:10.1136/jmg.2010.086553 


\section{Cohen syndrome diagnosis using whole genome arrays}

Nuria Rivera-Brugués, Beate Albrecht, Dagmar Wieczorek, Heinrich Schmidt, Thomas Keller, Ina Göhring, Arif B Ekici, Andreas Tzschach, Masoud Garshasbi, Kathlen Franke, Norman Klopp, H-Erich Wichmann, Thomas Meitinger, Tim M Strom and Maja Hempel

J Med Genet 2011 48: 136-140 originally published online October 4, 2010

doi: 10.1136/jmg.2010.082206

Updated information and services can be found at:

http://jmg.bmj.com/content/48/2/136

These include:

References This article cites 13 articles, 4 of which you can access for free at: http://jmg.bmj.com/content/48/2/136\#BIBL

Email alerting

Receive free email alerts when new articles cite this article. Sign up in the service box at the top right corner of the online article.

Topic Articles on similar topics can be found in the following collections

Collections

Molecular genetics (1178)

Epidemiology (585)

Genetic screening / counselling (805)

Obesity (nutrition) (54)

\section{Notes}

To request permissions go to:

http://group.bmj.com/group/rights-licensing/permissions

To order reprints go to:

http://journals.bmj.com/cgi/reprintform

To subscribe to BMJ go to:

http://group.bmj.com/subscribe/ 